\title{
PERAN GENDER DAN INTERVAL PUASA PADA PROFIL LIPID TIKUS WISTAR DENGAN DIET ATHEROGENIK
}

\author{
$\underline{\text { Rahma Triliana }}^{\text {1) }}$, Hardadi Airlangga ${ }^{2)}$ \\ ${ }^{1}$ Fakultas Kedokteran, Universitas Islam Malang/UNISMA \\ email: rahmatriliana@unisma.ac.id, hardadiairlangga@unisma.ac.id
}

\begin{abstract}
Introduction: Atherogenic diet can induced.hyperlipidemia leading to abnormal lipid profile. Time restricted feeding is proposed as treatment for hyperlipidemia. However, the effect of gender and which type of time-restricted feeding is the best to alter lipid profile is unknown.

Method: The study was conducted in female and male wistar rats which was devided into 5 groups, Negative Control (KN, $n=8)$, Positive Control (KP, $n=8)$, Daily restricted group (KRam, $n=8)$, alternate restricted group (KDaud, $n=8$ ) and Monday-Thursday restricted group (KSeKa, $n=8$ ) respectively. Atherogenic diet were administrated for six weeks followed by 4 weeks of timerestricted feeding. At 15 weeks of age, all rats were humanely culled and serum samples were collected for analyses. Lipid profile were assesed using spectrophotometry and analysed using two way Anova followed by post hoc LSD and $p<0.05$ is considered as statiscally significant.

Results: Gender and time restricted feeding affects serum total cholesterol and non-HDL cholesterol levels while gender influenced HDL and time restricted feeding influenced LDL levels. Both gender and time restricted feeding did not altered trigliseride level. Interestingly, no significant differences were found in lipid profile of $K N$ vs KP in male or female group. Time restricted feeding had no significant effect in male but significant effect on female with higher, undesireable lipid profile.
\end{abstract}

Conclusion: Atherogenic diets did not lipid profile in male or female rats, but higher lipid profile were observed in female with atherogenic diet. Time restricted feeding has gender related effect cholesterol and non-HDL cholesterol level, but no gender effect on LDL. HDL is solely dependent on gender and not affected by atherogenic diet or time restricted feeding.

Keywords: Atherogenic diet, Time-restricted feeding,HDL, LDL, Triglyceride, Cholesterol.

\section{PENDAHULUAN}

Obesitas dapat meningkatkan insiden penyakit degeneratif dan kecacatan serta kematian dini [1]. Obesitas pada orang dewasa diperkirakan sebesar $15,4 \%$ dengan 16 provinsi memiliki angka prevalensi obesitas diatas rata-rata nasional [2]. Diperkirakan 1 dari 5 anak di negara maju mengalami obesitas sedangkan di Indonesia, angka obesitas adalah $18,8 \%$ pada anak usia $5-12$ tahun, $10.8 \%$ untuk usia 13-15 tahun dan $7.3 \%$ pada remaja usia $16-18$ tahun dengan 13-15 propinsi berada diatas rata-rata nasional [2] sehingga obesitas pada anak telah menjadi masalah nasional yang perlu segera ditangani.

Obesitas disebabkan oleh ketidakseimbangan asupan energi (makanan) dengan pengeluaran energi dalam waktu lama yang lama. terutama akibat diet tinggi karbohidrat dan lemak [3]. Salah satu formulasi diet tinggi lemak pada hewan coba, adalah diet atherogenik [4]. Diet atherogenik diketahui menyebabkan peningkatan berat badan, perubahan profil lipid, terjadinya perlemakan hepar dan meningkatkan pembentukan sel busa atau menginduksi proses atherosklerosis pada tikus.

Terapi obesitas saat ini adalah pengaturan asupan makanan, olahraga,

farmakoterapi dan operasi/Bariatric surgery[3]. Obesitas pada anak-anak sebaiknya tidak menggunakan terapi farmakologis atau terapi bedah karena efek sampingyang belum pasti.Oleh sebab itu, modifikasi gaya hidup dengan pengendalian asupan makanan dan olahraga atau peningkatan aktifitas fisik merupakan terapi pilihan utama untuk obesitas pada anak. 
Puasa merupakan kewajiban Muslim yang diketahui bermanfaat bagi tubuh dan mulai dibiasakan pada anak sejak usia 7tahun. Puasa selain bersifat ibadah, juga memiliki manfaat kesehatan serta aman pada anak-anak bahkan pada menderita DM type-1 sekalipun [5]. Puasa dapat menurunkan kadar ApoB dan meningkatkan kadar ApoAI serum sehingga puasa dapat meregulasi metabolisme apolipoprotein [6] dan merubah kadar kolesterol total dan HDL serum

Dalam Islam selain puasa Ramadan, ada beberapa tipe puasa yang lain misalnya puasa Senin-Kamis dan puasa Daud. Puasa SeninKamis adalah puasa yang dilakukan secara rutin setiap hari Senin dan hari Kamis, sedangkan puasa Daud adalah puasa yang dilakukan secara bergantian (sehari puasa dan sehari tidak). Penelitian yang membandingkan efek puasa tipe Senin-Kamis, puasa tipe Daud, dan puasa tipe Ramadan (setiap hari puasa) pada kesehatan belum pernah dilakukan, sehingga perlu dilakukan untuk menentukan jenis puasa yang terbaik untuk kesehatan.

Efek berbagai tipe puasa pada terjadinya hiperlipidemia dan obesitas pada hewan coba tikus terutama tikus muda belum diketahui karena diduga tikus tidak dapat dipuasakan. Namun pada review tentang puasa pada tikus menjelaskan bahwa tikus dapat dipuasakan selama 4 - 24 jam tergantung durasi/lamanya penelitian [7]. Perlakuan puasa pada tikus pada malam hari selama 11-12 jam sehari tidak menyebabkn distresspada tikus[7] sehingga pengkajian efek puasa pada tikus dengan diet tinggi lemak dapat dilakukan.

Metabolisme lipid juga diregulasi oleh hormon steroid sehingga jenis kelamin akan mempengaruhi metabolisme tubuh saat hiperlipidemia. Peran gender dan berbagai jenis puasa pada perubahan profil lemak yakni kolesterol total, Trigliserida, HDL, LDLdan non HDL-Kolesterol dengan diet atherogenik belum pernah dilakukan sehingga perlu diteliti secara utuh untuk mengetahui jenispuasa yang terbaik terkait dengan perbedaan gender/jenis kelamin dalam memperbaiki profil lipid.

\section{METODE PENELITIAN}

\section{Desain Penelitian}

Penelitian dilakukan secara experimental laboratorik (True Experimental Study Design) dengan kontrol (post test control group design) secara in-vivo pada tikus wistar (Rattus novergicus) jantan dan betina. Penelitian dilakukan diAnimal House FK UNISMA untuk pemeliharaan hewan coba, Lab. Biokimia FK UNISMA untuk pembedahan hewan coba, dan Lab. Patologi Klinik FK Univ. Brawijaya untuk pemeriksaan marker penelitian. Penelitian dilakukan dari bulan November 2016 sampai dengan Mei 2017.

\section{Etika Penelitian}

Penelitian ini telah mendapat surat layak etik dari Komisi Etik Penelitian (Animal Care and Use Commited) Universitas Brawijaya dengan nomor 639-KEP-UB dan disetujui pada tanggal 10 Oktober 2016

\section{Hewan Coba}

Penelitian ini menggunakan hewan coba tikus wistar (Rattus novergicus) jantan dan betina yang berusia 5 minggu. Baik tikus jantan maupun betina masing-masing dikelompokkan menjadi 5 kelompok yaitu kontrol negatif $(\mathrm{KN})$ dengan $\mathrm{n}=8$, kontrol positif (KP) dengan $n=8$, kelompok setiap hari (KRam) dengan $\mathrm{n}=8$, kelompok dua hari (KDaud) dengan $n=8$ dan kelompok SeninKamis $(\mathrm{KSeKa})$ dengan $\mathrm{n}=8$

Pemberian diet standart diberikan pada $\mathrm{KN}$ dan perlakuan diet atherogenik diberikan pada KP, KRam, KDaud dan KSeKa selama 10 minggu. Perlakuan diberikan mulai minggu ke-7 pada KRam, KDaud dan KSeKa. Penimbangan berat badan tikus dilakukan satu minggu sekali pada akhir minggu dan konsumsi pakan diambil setiap hari.

\section{Pemberian Diet Atherogenik}

Diet atherogenik dilakukan pada KP, KRam, KDaud dan KSeKadengan mencampurkan 20 gr konsentrat pakan ayam (PARS), 10 gr tepung terigu, 0,2 gr kolesterol, $0,02 \mathrm{gr}$ asam kolat dan air secukupnya kemudian ditambah $1 \mathrm{ml}$ minyak babi. Berat pakan rerata kering 1 ekor tikus adalah 30 gr/hari.

\section{Perlakuan Puasa}

Perlakuan puasa dilakukan pada hewan coba berusia 11 minggu dan telah tempatkan pada single cage selama 4 minggu dengan diet atherogenik pada KRam, KDaud dan 
KSeKa. Puasa dilakukan selama 11 jam, dengan cara memberikan makanan pada pukul 07.00 WIB dan diambil pukul 20.00 WIB karena tikus adalah hewan nokturnal.

Perlakuan Puasa pada Kram dilakukan dengan mengambil makanan setiap hari, pada KDaud dua hari sekali secara bergantian (sehari diambil sehari tidak) dan pada KSeKa, setiap hari Senin dan Kamis..

\section{Pembunuhan Hewan Coba dan Pengambilan Serum}

Sebelum dikorbankan, tikus dipuasakan selama 11 jam kemudian dianastesi dengan menggunakan ketamin $(5 \mathrm{mg} / 100 \mathrm{grBB})$

secara intramuskular. Kepala tikus dimasukkan ke dalam gelas bekerberisi kapas kloroform. Abdomen tikus kemudian dibedah dan dilakukan pengambilan darah intrakardial menggunakan spuit disposible sebanyak $5 \mathrm{cc}$.

Sampel darah yang diperoleh kemuidan dimasukkan dalam tabung vacutainer tanpa EDTA dan didiamkan selama \pm 60 menit pada suhu kamar. Setelah mengalami koagulasi, darah disentrifugasi selama 15 menit dengan kecepatan 3600 rpm. Serum kemudian diambil dan dipisahkan untuk pemeriksaan marker kimia darah

\section{Pemeriksaan Profil Lipid}

Profil lipid darah yang dianalisa adalah kolesterol, trigliserida, HDL dan LDL. Kolesterol, trigliserida dan HDL diukur dengan spektrofotometri sedangkan LDL diukur dengan metode LDL direk dengan spektrofotometri. Kadar Non-HDL kolesterol diukur dengan rumus kadar kolesterol total dikurangi kadar HDL.

\section{Teknik Analisa Data}

Data penelitian yang diperoleh dianalisa dengan dengan uji two-way-ANOVA dilanjutkan dengan uji post hoc Least Significant Difference (LSD) dengan tingkat kebermaknaanbila $\mathrm{p}<0,05$.

\section{HASIL DAN PEMBAHASAN}

Hasil profil lipid jantan dan betina pada penelitian ini tergambar pada tabel

A.

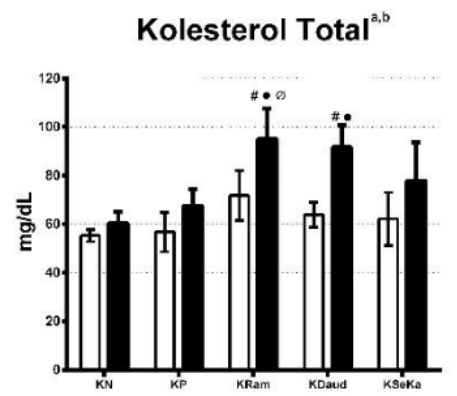

D.

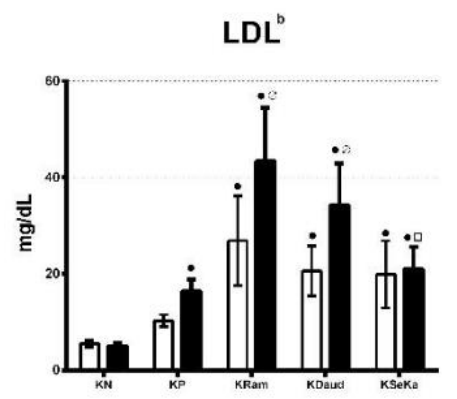

B.

Trigliserida

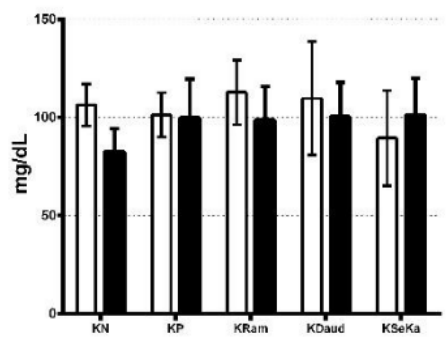

E.

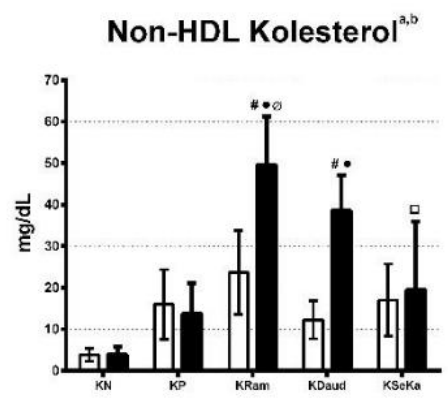

c.
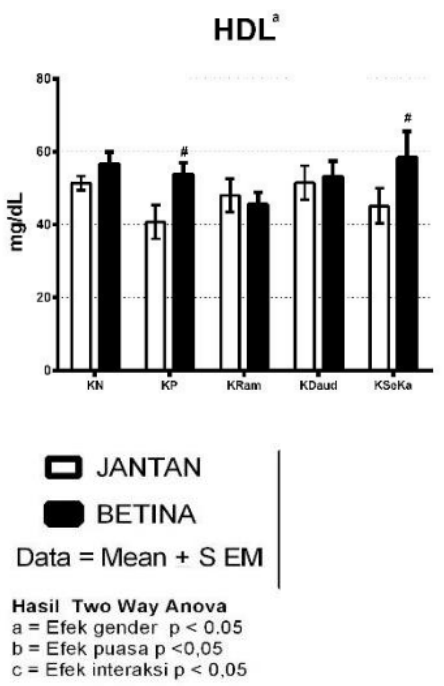

KN $\quad$ = Kelompok Kontrol Negatif $\begin{array}{ll}\text { KP } & =\text { Kelompok Kontrol Positif } \\ \text { KRam } & =\text { Kelompok Puasa Ramadan }\end{array}$ $\begin{array}{ll}K R a m & =\text { Kelompok Puasa Ramadan } \\ \text { KDaud } & \text { Kelompok Puasa Daud }\end{array}$ $\begin{aligned} \text { KDaud } & =\text { Kelompok Puasa Daud } \\ \text { KSeKa } & =\text { Kelompok Puasa Senin Kamis }\end{aligned}$ Hasil Post Hoc LSD Dalam Jenis Kelamin Yang Sama $\bullet=p<0,05$ vs KN $\quad=p<0,05$ vs KP
$=p<0.05$ vS KRam $=p<0,05$ vs KDaud $\square=p<0,05$ vs KRam $\quad=p<0,05$ vs KDaud
$\forall=p<0,05$ vs KSeKa $\#=$ LSD $p<0.05$ vs Jantan

Gambar 1. Hasil Profil Lipid Kelompok Jantan dan Kelompok Betina Dengan Diet Atherogenik dan Berbagai Jenis Puasa 
Dari gambar 1.A didapatkan adanya peran jenis kelamin dan tipe puasa pada perubahan kadar kolesterol serum darah tikus. Uji LSD menunjukkan perbedaan yang signifikan antara kelompok jantan vs kelompok betina pada puasa Ramadan dan puasa Daud, dengan kadar kolesterol yang relatif lebih tinggi daripada kontrol yang tidak dipuasakan. Efek puasa lebih nyata pada kelompok betina dibandingkan kelompok jantan, dengan perbedaan yang signifikan antara kelompok puasa Ramadan dan puasa Daud dengan diet athreogenik jika dibandingkan dengan kontrol negatif dan pada puasa Ramadan jika dibandingkan dengan kontrol positif.

Data diatas menunjukkan bahwa pada wanita, efek berbahaya dari diet atherogenik lebih nyata dan lebih poten jika dibandingkan pada pria, dimana terjadi peningkatan kadar kolesterol total dalam darah pada saat puasa. Hal ini tentu bertentangan dengan ide dasar bahwa puasa akan meregulasi metabolisme lipid dan menjadi re-setter metabolisme. Penelitian ini membuktikan bahwa pada wanita, puasa dengan diet yang atherogenik atau hiperlipidemik justru dapat mengubah profil kolesterol menjadi profil yang 'undesireable' dan mungkin berisiko pada peningkatan insiden atherosklerosis di usia tua serta peningkatan risiko obesitas dengan berpuasa.

Penelitian lanjutan perlu dikembangkan mengingat penelitian ini tidak mengobservasi adanya perubahan ritme sirkardian tikus yang dikenal sebagai hewan nokturnal. Kemungkinan tikus betina saat dipuasakan, justru berpindah pola makan dan menjadi tikus yang dominan diurnal sedangkan pada jantan tidak. Hal ini diduga terjadi akibat

perbedaan fundamental dari sumbu hipotalamus-hipofise-gonad (HHG) antara pria dan wanita yang berpengaruh pada fisiologi lapar-kenyang dan keinginan untuk makan. Asarian dan Greary, 2013 dalam reviewnya menyebutkan adanya perbedaan gender pada kendali jumlah makanan yang dikonsumsi pada mencit, tikus, monyet dan manusia yang sebagai hasil interaksi antara efek hormon reproduksi dan aktivasi dari androgen dan estrogen. [8] Perbedaan ini dimediasi oleh perubahan kemampuan orosensori, mekanopersepsi gaster, ghrelin, insulin, dan leptin serta kendali makan dan nafsu makan di sentral melalui serotonin, neuropeptide $Y$, Agouti-related peptide (AgRP), dan dopamin yang dimodulasi oleh sumbu HHG ini [8]. Kondisi ini dapat turut berperan pada mekanisme terjadinya obesitas dan binge eating atau perubahan fase/ritme sirkardian hewan coba dan mungkin manusia yang semuanya membutuhkan penelitian lanjutan untuk menganalisa perbedaan ini.

Gambar 1.B menunjukkan tidak adanya efek gender maupun puasa pada kadar trigliserida. Hal ini dapat dipahami mengingat trigliserida dominan dipengaruhi oleh asupan makanan. Selain itu, saat berpuasa akan menurunkan kadar trigliserida sehingga sebanding antara kelompok jantan dan betina karena pada penelitian ini, sebelum dibunuh, tikus dipuasakan terlebih dahulu

Dari gambar 1.C. didapatkan adanya peran jenis kelamin pada kadar HDL serum kelompok kontrol positif dan kelompok puasa Senin Kamis tanpa ada perbedaan antar kelompok perlakuan baik kelompok jantan maupun kelompok betina pada hasil uji post hoc LSD. Kadar HDL pada tikus betina cenderung lebih tinggi dibandingkan tikus jantan.Hal ini sudah menjadi pengetahuan umum dan sudah menjadi standar dalam pemeriksaan laboratorium HDL serum dengan kadar wanita yang memiliki angka normal lebih tinggi (> $55 \mathrm{mg} / \mathrm{dL}$ ) daripada pria $(>45 \mathrm{mg} / \mathrm{dL})$.

Estrogen berperan penting dalam memodulasi metabolisme lipid, menghambat proses inflamation, homeostasis pembuluh darah, mengendalikan fungsi endotel, dan progresi plak sehingga berkontribusi pada rendahnya prevalensi penyakit vaskular atherosklerosis saat premenopause [9]. Pemberian terapi esterogen memberikan efek baik berupa peningkatan kadar HDL dan penurunan kadar LDL, perbaikan metabolisme glukosa walaupun berisiko terjadinya trombus (estrogen-induced thrombus) [10].

Perbedaan gender pada kadar HDL nampak bermakna saat diberikan diet atherogenik dan perlakuan puasa senin kamis dibandingkan dengan diet normal walaupun kadar HDL-nya lebih tinggi. Data diatas menunjukkan bahwa pada wanita diet atherogenik akan menyebabkan peningkatan pembentukan HDL sedangkan pada pria cenderung terjadi penurunan HDL sehingga 
perbedaan kadar HDL menjadi semakin nyata. Puasa dengan diet atherogenik justru terkesan mengembalikan kadar HDL pada level normal dan bahkan pada puasa setiap hari (Ramadan), kadar HDL lebih rendah pada wanita dibandingkan pria walaupun tidak signifikan.

Hal diatas diduga karena High density lipoprotein (HDL) berperan penting pada proses reverse cholesterol transport ke hepar dan ke jaringan pembentuk hormon steroid (steroidogenic tissues) dengan mekanisme yang dikenal dengan "selective lipid uptake" yang diperantarai oleh scavenger receptor $B$ type I (SR-BI). [11]. Saat kolesterol dalam asupan makanan tinggi, maka hormon esterogen akan memfasilitasi sintesa HDL melalui regulasi gen pengkode SRBI.sehingga kadar HDL akan meningkat dan transport kolesterol akan terperbaiki.

Mekanisme molekular lanjutan yang melibatkan perubahan kadar HDL dan jalur reverse cholesterol transport pada perempuan pre-menopause deangn berbagai komposisi diet perlu diteliti lebih lanjut dan komprehensif

Puasa pada pria maupun wanita tidak memberikan pengaruh yang bermakna pada kadar HDL. Hal ini menunjukkan bahwa sintesa dan produksi HDL lebih didominasi oleh perbedaan genetik dalam hal ini jenis kelamin, hormonal dan mungkin komposisi diet namun tidak dipengaruhi oleh interval pembatasan waktu makan dan atau pembatasan jumlah makanan yang dikonsumi. Pada penelitian ini, asupan makan mingguan kelompok tikus dengan puasa harian / Ramadan memang lebih rendah dibandingkan kelompok lain (data tidak ditunjukkan) pada jantan maupun betina, namun hal ini tetap tidak memperbaiki atau meningkatkan kadar HDL. Artinya, pembatasan waktu makan belum terbukti memiliki efek protektif dalam kondisi asupan makanan yang tinggi lemak. Oleh sebab itu, terapi diet dengan pembatasan waktu makan sebaiknya tetap menggunakan komposisi diet yang baik (non atherogenik) dan tidak hanya penjarangkan waktu makan atau mengurangi asupan tanpa perubahan komposisi diet.

Kadar LDL pada gambar 1.D menunjukkan efek puasa yang lebih dominan dibandingkan efek gender baik pada jantan maupun betina. Perbedaan diet menyebabkan perbedaan kadar LDL yang signifikan dengan kelompok kontrol positif baik pada jantan maupun betina sehingga dapat dipastikan bahwa diet atherogenik menyebabkan terjadinya peningkatan LDL pada jantan maupun betina.

Kadar LDL lebih tinggi pada betinda dibandingkan jantan dan berbeda secara signifikan dengan kelompok kontrol positif. Hal ini menunjukkan bahwa puasa dan diet atherogenik pada wanita justru memiliki efek yang tidak baik. Makin sering puasa dilakukan, makin tinggi kadar LDL pada wanita (dan pria, walaupun tidak berbeda signifikan dengan kontrol positif kelompok jantan).

Hal ini tidak sesuai dengan penelitian penelitian sebelumnya yang menunjukkan efek baik puasa pada kadar LDL [12, 13]. Hal ini mungkin perbedaan subyek penelitian serta pengaruh aktifitas fisik dan atau kepatuhan subyek penelitian terhadap protokol penelitian. Kepatuhan subyek pada protokol penelitian sulit dicapat pada penelitian tikus karena pengendalian aktifitas tikus dan konsumsi makanannya tidak dapat dilakukan dengan tegas karena tikus beradaptasi dengan perubahan yang ada. Kemungkinan saat dipuasakan di malam hari, tikus merubah pola makannya sehingga mengkonsumsi makanan lebih banyak di malam hari. Perubahan pola sirkardian ini dapat berefek buruk pada tubuh termasuk perubahan profil lipid.

Kadar non-HDL kolesterol adalah salah satu marker lain yang dari profil lipid yang dapat dievaluasi untuk menilai perubahan profil lipid. Pada analisa data didapatkan bahwa gender dan tipe puasa berpengaruh pada kadar non-HDL kolesterol dengan perbedaan yang signifikan pada kelompok puasa ramadan dan puasa Daud. Nilai nonHDL kolesterol yang lebih tinggi pada kelompok betina dibandingkan kelompok jantan dan perbedaan yang signifikan dengan kontrol positif semakin menguatkan efek buruk dari diet atherogenik pada wanita yang berpuasa.

Puasa seharusnya dapat menjadi faktor yang akan meregulasi kadar lemak dalam darah dan memperbaiki profil lipid. Namun hal ini tidak begitu nampak pada penelitian ini terutama pada subyek wanita. Penelitian lanjutan diatas untuk mengkonfirmasi kondisi 
ini pada subyek wanita, pre-menopause dengan obesitas dan tanpa obesitas saat

berpuasa perlu dilakukan untuk mengkonfirmasi temuan ini pada manusia.

Selain itu, analisa mekanisme

molekular puasa dalam meregulasi metabolisme lipid dengan komposisi diet yang berbeda-beda guna menghasilkan formulasi diet dapat di-tailor-made sesuai dengan kondisi pasien perlu dilakukan terutama terkait dengan hormon sex. Mekanisme regulasi metabolisme lipid terkait gender seperti analisa jalur reseptor esterogen, reseptor testosteron/androgen dan aktifitasnya akan menambah pemahaman tentang temuan penelitian ini.

\section{KESIMPULAN}

Berdasarkan hasil temuan penelitian ini dapat disimpulkan bahwa gender berperan pada perubahan profil lipid terutama HDL, dan kolesterol total. Puasa berpengaruh pada regulasi kadar LDL sedangkan kadar trigliserida tidak dipengaruhi oleh puasa maupun gender. Puasa dengan diet atherogenik memiliki efek hiperlipidemia pada perempuan dan tidak berefek secara signifikan pada pria.

\section{UCAPAN TERIMA KASIH}

Direktorat Riset dan Pengabdian Masyarakat Direktorat Jenderal Penguatan Riset dan Pengembangan, Kementrian Riset, Teknologi dan Perguruan Tinggi Kontrak Nomor:

120/SP2H/LT/DPRM/IV/2017 pendanaan penelitian dan tim 16 tahun 2017 untuk pelaksanaan proses penelitian dan dukungan teknis.

\section{REFERENSI}

1. World Health Organization, Global Nutrition Targets 2025. Childhood Overweight. Policy Brief, W.H. Organization, Editor. 2012, WHO/NMH/NHD/14.6. p. 1-8.

2. Balitbangkes, Riset Kesehatan Dasar (Riskesdas 2013), B.P.d.P.K.K.K.R. Indonesia, Editor. 2013: Jakarta.

3. Reilly, J.J., Obesity in childhood and adolescence: evidence based clinical and public health perspectives. Postgraduate
Medical Journal, 2006. 82.(969): p. 429437.

4. Triliana, R., D.W. Soeatmadji, and H. Kalim, Pengaruh Terapi Suplementasi Fitosterol pada Profil Lemak Plasma, Kadar Apolipoprotein (Apo) B-48, dan Penghitungan Sel Busa Aorta Tikus Pascadiet Atherogenik. Journal of Experimental Life Science, 2012. 2(2): p. $70-81$.

5. AlAlwan, I. and A. AlBanyan, Effects of Ramadan fasting on children with Type 1 diabetes. International Journal of Diabetes Mellitus, 2010. 2 p. 127-129.

6. Adlouni, A., et al., Beneficial effect on serum apo AI, apo B and Lp AI levels of Ramadan fasting. Clinica Chimica Acta, 1998. 271 p. 179-189.

7. Jensen, T.L., et al., Fasting of mice: $a$ review. . Laboratory Animals, 2013. 47(4): p. 225-40.

8. Asarian, L. and N. Geary, Sex differences in the physiology of eating. Am J Physiol Regul Integr Comp Physiol, 2013. 305(11): p. R1215-67.

9. Barton,M.,Cholesteroland atherosclerosis: modulation by oestrogen. Curr Opin Lipidol, 2013. 24(3): p. 214-20.

10. Bush, T.L. and E. Barrett-Connor, Noncontraceptive estrogen use and cardiovascular disease. Epidemiol Rev, 1985. 7: p. 89-104.

11. Lopez, D. and M.P. McLean, Estrogen regulation of the scavenger receptor class $B$ gene: Anti-atherogenic or steroidogenic, is there a priority? Mol Cell Endocrinol, 2006. 247(1-2): p. 2233.

12. Masuda, D., et al., Fasting serum apolipoprotein B-48 can be a marker of postprandial hyperlipidemia. $\mathrm{J}$ Atheroscler Thromb, 2011. 18(12): p. 1062-70.

13. Browning, J.D. and J.D. Horton, Fasting reduces plasma proprotein convertase, subtilisin/kexin type 9 and cholesterol biosynthesis in humans. J Lipid Res, 2010. 51(11): p. 3359-63. 